\title{
Property enhancement of lightweight aggregate by carbonation processing
}

\author{
Junyoung Park, Yootaek $\mathrm{Kim}^{\dagger}$ and Yunjae Choi \\ Department of the Materials Engineering, Kyonggi University, Suwon 443-760, Korea
}

(Received September 17, 2012)

(Revised September 28, 2012)

(Accepted October 12, 2012)

\begin{abstract}
The mechanical property enhancement was studied using fly ash produced from fluidized bed type boiler in power plant, which contains a lot of $\mathrm{Ca}$ component being used to carbonate for $\mathrm{CO}_{2}$ fixation in the lightweight aggregates made of cement and some portion of fly ash as a cement substitution under the supercritical condition. Specimens having various fly ash substitution rates and curing periods were carbonated under the supercritical condition at $40^{\circ} \mathrm{C}$. The weight change rate, carbonation rate by TG/DTA analysis, $1 \%$ Phenolphthalein test, specific gravity and mechanical compression strength test were performed to observe the mechanical property enhancement of the cemented materials after carbonation under the supercritical condition and to make sure those could be classified as lightweight aggregates having specific gravity under 2.0 .
\end{abstract}

Key words Carbonation, Fly ash, Supercritical condition, Lightweight aggregate

\section{인공경량골재의 탄산화 반응에 따른 물성향상에 관한 연구}

박준영, 김유택 ${ }^{\dagger}$, 최윤재

경기대학교 일반대학원 신소재공학과, 수원, 443-760

(2012년 9월 17일 접수)

(2012년 9월 28일 심사완료)

(2012년 10월 12일 게재확정)

요 약 순환유동층 연소방식의 화력발전소에서 석탄을 연소시킨 후 발생하는 석탄재 중 탄산화 반응 인자인 $\mathrm{Ca}$ 성분 을 다량 포함한 비산회를 시멘트에 일정량 치환하여 제조한 인공경량 경화체를 초임계상태에서 이산화탄소 $\left(\mathrm{CO}_{2}\right)$ 를 고정화 하여 골재의 기계적 물성향상을 도모하였다. 초임계 분위기 $40^{\circ} \mathrm{C}$ 조건에서 비산회의 치환량을 변화시켜 재령일수별 탄산화 를 시행하였다. 비산회 치환량에 따른 탄산화 반응시킨 인공경량골재 경화체의 무게변화율, TG/DTA 분석, $1 \%$ 페놀프탈레 인 알칼리성 측정을 통하여 탄산화 진행여부를 확인하였으며 28 일까지의 재령 이후 경화체의 압축강도 측정과 비중측정을 통하여 골재의 기계적 물성향상과 인공경량골재의 기준 비중치인 2.0 이하의 비중값을 갖는 탄소고정 인공경량골재 경화체 를 얻는 것이 가능할 것으로 판단되었다.

\section{1. 서 론}

화력발전소에서 석탄을 연소하여 발생되는 산업부산물 인 석탄재는 포집 방법에 따라 크게 저회(Bottom Ash) 와 비산회(Fly Ash)로 구분되며[1-3] 연소방식 또한 미 분탄 연소방식과 순환유동층 연소방식으로 구분된다. 미 분탄 연소방식으로 발생되는 비산회의 경우 $80 \%$ 이상 이 콘크리트 혼화재 및 시멘트의 원료로 활발히 재활용

\footnotetext{
Corresponding author

Tel: +82-31-249-9765

Fax: +82-31-244-6300

E-mail: ytkim@kgu.ac.kr
}

되고 있다. 이에 반해 순환유동층 방식의 비산회는 ASTM C타입 Fly Ash로 높은 칼슘 함량을 포함하고 높은 팽창 율을 나타내며 이로 인해 콘크리트 및 각종 시멘트 경화 체의 성능이 거의 향상되지 않는 것으로 발표되어 있으 며[4-6], 국내에서는 $\mathrm{KS}$ 규격(KS L 5405)에 부합하지 못 하여 재활용되지 못하고 전량 매립되고 있는 실정으로 이에 대한 방안이 절실히 요구되고 있다[7].

순환유동층 방식에서 발생한 비산회에는 알칼리 토금 속을 함유한 $\mathrm{CaO}$ 와 $\mathrm{MgO}$ 화합물 성분이 다량 함유되어 있기 때문에 이산화탄소를 내부에 안정하게 고정시키는 탄산화 반응을 통하여 재활용이 가능할 것으로 판단된다. 비산회는 가격이 저렴하여 경제성이 좋고, 만약 성공적 
으로 탄산화 되어 건자재 및 콘크리트 혼화재로 재활용 될 경우 콘크리트 경화체 조직의 치밀성, 시공성 개선, 장기강도 향상 등 많은 장점을 가지고 있다[8]. 이에 따 라 $\mathrm{Ca}(\mathrm{OH})_{2}$ 성분을 이용하여 이산화탄소를 주입 및 반 응 시키는 화학실험을 바탕으로 폐콘크리트 미분말(주로 시멘트 수화물)에 이산화탄소를 안정적으로 저장하여 활 용도를 높이는 방법이 연구되고 있다[9]. 시멘트 경화체 의 경우 기체 및 액체의 특성을 동시에 갖는 초임계 이 산화탄소를 사용하여 경화체 내부의 수화반응을 통해 생 성되는 $\mathrm{Ca}(\mathrm{OH})_{2}$ 를 $\mathrm{CaCO}_{3}$ 의 상으로 전환시키는 반응을 급속화시키며 내부에 생성된 미세한 기공을 반응생성물 로 메우는 효과를 얻음으로 시멘트 경화체의 내침출성과 기계적 물성을 향상시키는 방안이 연구되고 있다[10].

본 연구에서는 국내에서는 재활용되지 않고 있는 순환 유동층 비산회의 재활용을 위해 이를 시멘트 경화체에 일정량 치환하여 3 일, 14 일, 28 일간 상온, 상압 하에서 양생하여 높은 압축강도와 2.0 이하의 비중을 가진 파쇄 형 인공경량골재 경화체의 제조를 목적으로 실험을 진행 하였고 유동층 비산회에 포함된 $\mathrm{CaO}$ 성분으로 인한 골 재의 성능저하를 방지하기 위해 초임계 조건에서 이산화 탄소를 탄산화시켜 $\mathrm{CaCO}_{3}$ 로 상전환시킴으로서 최종적 인 골재의 물성향상을 도모하였다.

\section{2. 실험방법}

\section{1. 사용재료}

본 실험에서 사용된 시멘트는 국내산 보통 포틀랜드 시멘트를 사용하였으며 잔골재로는 입도 $0.08 \sim 2 \mathrm{~mm}$ 의 표준사를 사용하였다. 치환된 비산회 원료는 국내 $\mathrm{Y}$ 화 력발전소에서 발생된 ASTM C Type 비산회(Fly Ash) 로써 화학조성을 Table 1에 나타내었다. 사용된 비산회 의 주성분으로는 $\mathrm{CaO}$ 와 $\mathrm{SiO}_{2}$ 로 각각 $45.40 \%$ 와 $21.94 \%$ 로 구성되어 있다. 순환유동층 비산회로써 탈황처리를 위한 석회석 첨가로 $\mathrm{CaO}$ 의 함량이 높으며 황 $\left(\mathrm{SO}_{3}\right)$ 성분 함유량에 비해 상대적으로 다량 포함되어 있기 때문에 탄산화에 적합한 원료로 판단되었다.

\section{2. 배합비 및 실험방법}

본 실험의 배합 및 실험변수는 Table 2에 나타내었다.
Table 2

Mixture proportions of mortars

\begin{tabular}{llll}
\hline Specimen & C : FA & S/(C + FA) $(w t \%)$ & W/B (wt $)$ \\
\hline FA 10 & $9: 1$ & & \\
FA 20 & $8: 2$ & 20 & 34 \\
FA 30 & $7: 3$ & & \\
FA 40 & $6: 4$ & & \\
\hline
\end{tabular}

FA: fly ash, S: standard sand, C: cement, W/B: water/binder

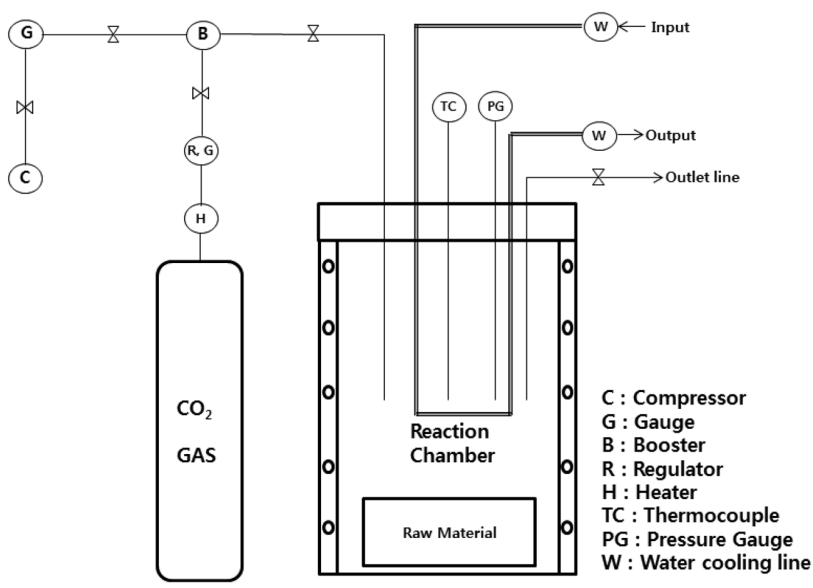

Fig. 1. Schematic diagram of the autoclave apparatus.

실험 변수로는 시멘트에 대한 비산회의 치환율로, 치환 율에 따른 탄산화율 및 물성을 비교하기 위해 $10 \%$, $20 \%, 30 \%, 40 \%$ 의 4수준으로 수행하였으며, 바인더비 표준사 첨가량 비율과 물-결합재비를 각각 $20 \%$ 와 $34 \%$ 로 고정시켰다. 배합된 원료를 모르타르 압축강도 측정 용 큐브몰드 $(50 \times 50 \times 50 \mathrm{~mm})$ 에 채워 넣고 다짐봉으로 수십 회 상부 충격을 가하여 원료 내 기포를 제거하였다. 제작된 시험체를 상온에서 24 시간 양생 후 몰드에서 탈 형하여 $3,14,28$ 일간 상온, 상압 양생 후 물성을 측정 하였으며 각 재령일수에 Autoclave 장비를 이용하여 초 임계 이산화탄소 분위기 조건인 $80 \mathrm{kgf} / \mathrm{cm}^{2}$ 의 압력과 $40^{\circ} \mathrm{C}$ 의 온도에서 Supercritical 탄산화를 시험체당 60 분 씩 반응시켜 초임계 탄산화에 따른 물성을 측정하였다. 실험에 사용한 탄산화 반응기인 Autoclave는 O-Ring Type의 Sealing이며 도식도는 Fig. 1에 나타내었으며 반 응기 내부에 압력센서와 열전대를 포함하여 실시간으로 온도와 압력의 변화를 측정할 수 있고 Booster 설비를 통해 $80 \mathrm{kgf} / \mathrm{cm}^{2}$ 의 압력을 유지할 수 있다. 탄산화율에 대한 실험분석으로는 탄산화 전, 후의 무게변화율과 압

Table 1

The elemental compositions of the fly ash (FA) expressed in oxide form

$(\mathrm{wt} \%)$

\begin{tabular}{|c|c|c|c|c|c|c|c|c|c|c|c|c|}
\hline \multirow{2}{*}{ FA } & $\mathrm{SiO}_{2}$ & $\mathrm{Al}_{2} \mathrm{O}_{3}$ & $\mathrm{Fe}_{2} \mathrm{O}_{3}$ & $\mathrm{CaO}$ & $\mathrm{MgO}$ & $\mathrm{Na}_{2} \mathrm{O}$ & $\mathrm{K}_{2} \mathrm{O}$ & $\mathrm{TiO}_{2}$ & $\mathrm{P}_{2} \mathrm{O}_{3}$ & $\mathrm{SO}_{3}$ & Ig. loss & Total \\
\hline & 21.94 & 8.53 & 6.05 & 45.4 & 6.06 & 0.06 & 0.48 & 0.5 & 0.08 & 4.26 & 6.65 & 100 \\
\hline
\end{tabular}


축강도를 측정하였으며 $1 \%$ 페놀프탈레인을 분무하여 탄산화 깊이를 확인하였고 TG/DTA 분석을 통하여 탄산 화율을 측정하였다. 또한 탄산화 전후의 절건비중을 측 정함으로서 인공경량골재의 조건인 2.0 이하의 비중을 만족하는 여부를 판단하였다.

\section{3. 결과 및 고찰}

비산회의 치환율에 따른 시멘트 경화체의 물성향상을 위하여 초임계 이산화탄소 조건에서의 탄산화 실험을 시 행하고 물성을 측정하였다. 실험의 조성으로는 Table 2 와 같이 시멘트 대비 비산회 치환율을 $\mathrm{FA} 10 \%, \mathrm{FA}$ $20 \%, \mathrm{FA} 30 \%, \mathrm{FA} 40 \%$ 로 배합한 조성을 사용하였으 며 3일, 14 일, 28일 상온, 상압 양생 후 각 재령일 마다 시험체를 초임계 이산화탄소 조건인 $80 \mathrm{kgf} / \mathrm{cm}^{2}$ 의 압력과 $40^{\circ} \mathrm{C}$ 의 온도하에서 초임계 탄산화를 진행하였으며 사용 된 분위기 조건 및 무게변화율을 Fig. 2에 나타내었다.

비산회 치환율에 따른 시멘트 경화체의 초임계 반응 분위기 조건 $\left(80 \mathrm{kgf} / \mathrm{cm}^{2}, 40^{\circ} \mathrm{C}-60 \mathrm{~min}\right)$ 에서의 무게변화

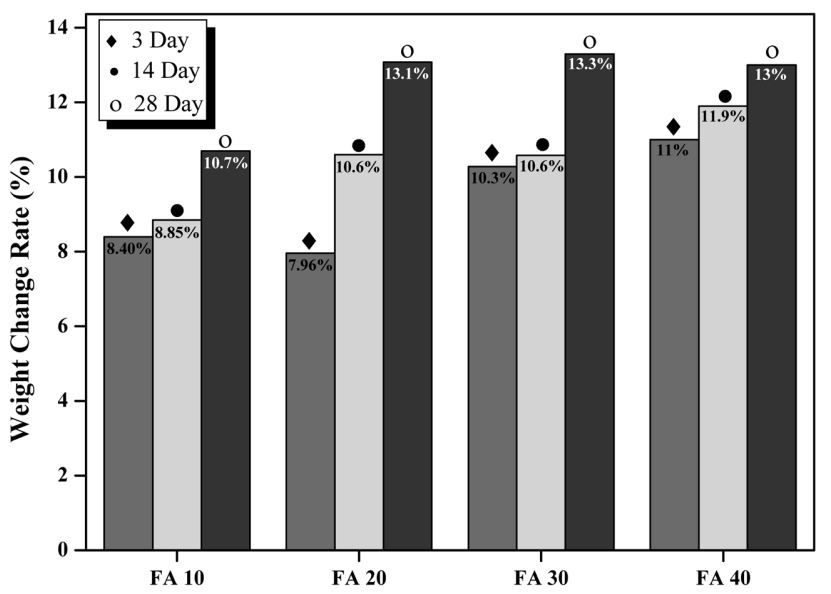

Fig. 2. Weight change of fly ash substituted mortars after carbonation under the supercritical condition $\left(80 \mathrm{kgf} / \mathrm{cm}^{2}\right.$ and $40^{\circ} \mathrm{C}$ $60 \mathrm{~min})$

율은 각 각 치환율에 상관없이 28 일 재령일에서 가장 높은 변화율을 나타내었으며, 비산회 치환율이 높을수록 재령일별 탄산화에 따른 무게변화율이 상대적으로 높은 것을 확인할 수 있었다. 비산회 치환율이 $40 \%$ 의 경우

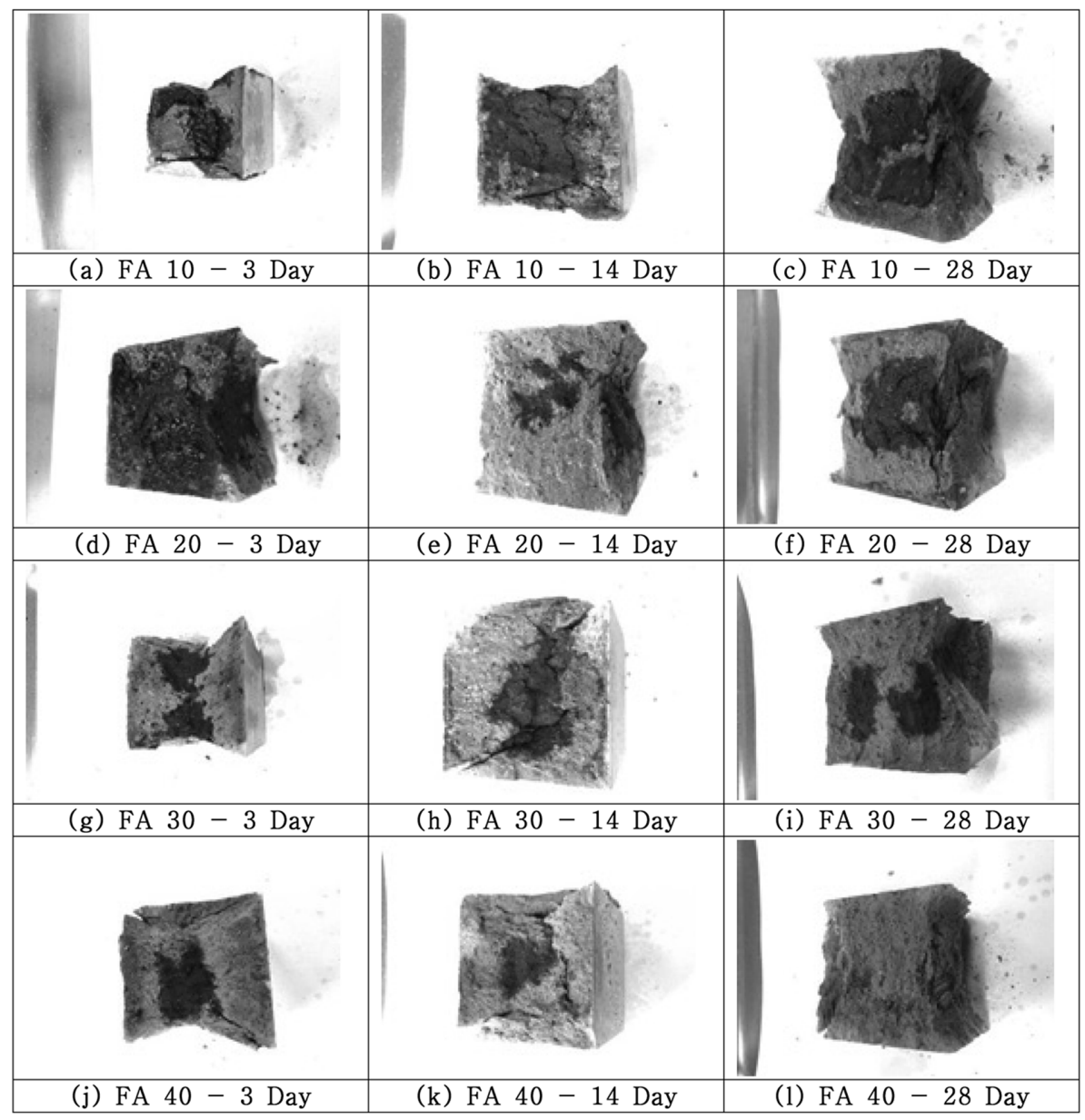

Fig. 3. Carbonation depth of fly ash substituted mortars after carbonation. 
각 3 일, 14 일, 28 일 재령일수별 무게변화율이 $11 \%$, $11.9 \%, 13 \%$ 를 나타내고 있으며 치환율 $10,20,30 \%$ 의 시편들에 비해 상대적으로 높은 증가율을 보이고 있 다. 이는 비산회 및 시멘트의 탄산화 반응 인자인 수화 반응에 따른 $\mathrm{Ca}(\mathrm{OH})_{2}$ 성분이 재령일수가 길어질수록 많 이 생성되어 초임계 탄산화 반응 시 높은 무게변화율을 나타내었으며 비산회 치환율이 높을수록 원료 내 포졸란 반응에 참여하지 않는 free- $\mathrm{CaO}$ 의 함량이 많아져 높은 탄산화 무게변화율을 나타내는 것으로 사료된다. 비산회 치환에 따른 초임계 이산화탄소 탄산화 촉진 깊이를 확인하기 위하여 시험체 파단면에 $1 \%$ 페놀프탈 레인 용액을 분무하고 알칼리성에 의한 변색을 통하여 탄산화를 확인하였으며 이를 Fig. 3에 나타내었다. $1 \%$ 페놀프탈레인 용액이 분무된 시편의 파단면을 확인해보 면 재령일이 증가할수록 무게변화율과 일관성 있게 탄산 화 깊이가 증가하는 것으로 보이며 또한 비산회의 치환 량이 증가할수록 시편의 탄산화 깊이가 증가하는 것으로 보인다. 시편 FA 40 의 28 일차에서는 다른 시편과 다르게 적색으로 변색된 부분이 미미하게 남아있는 것으로 보아 비산회의 free-CaO가 거의 모두 이산화탄소와 반응하여

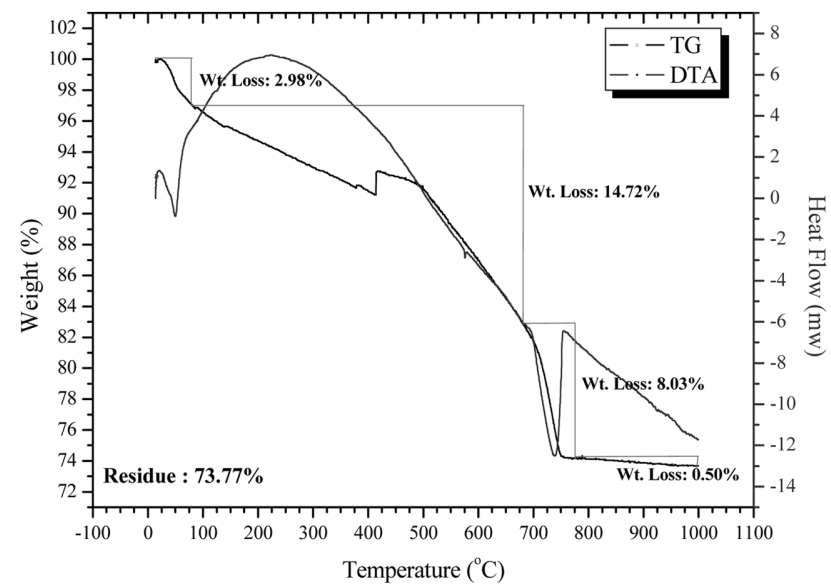

(a)

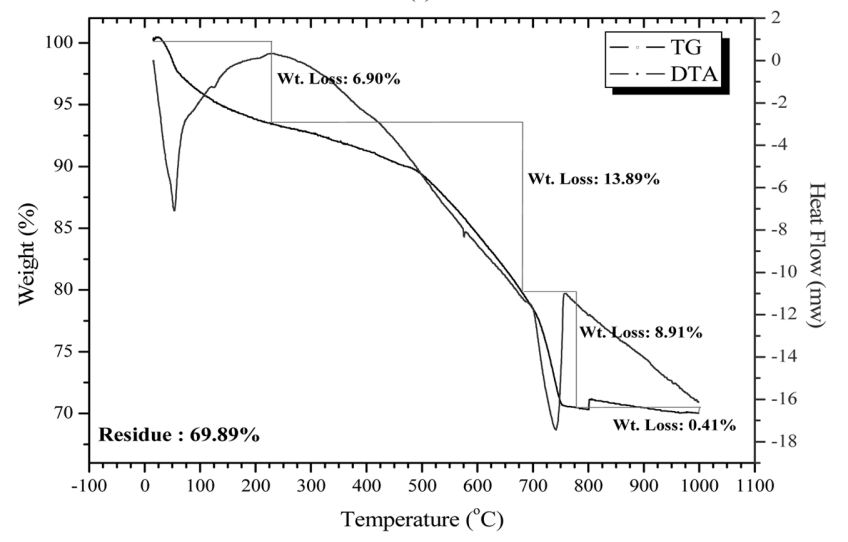

(c)
가장 높은 탄산화 반응이 일어난 것으로 판단된다.

이산화탄소의 탄산화 효율을 확인하기 위해 재령 28 일차에서 탄산화 시킨 각 시험체의 TG/DTA 분석을 측 정하여 Fig. 4에 나타내었다. Fig. 4의 (a), (b), (c), (d) 는 각각 FA $10, \mathrm{FA} 20, \mathrm{FA} 30, \mathrm{FA} \mathrm{40}$ 의 28 일 재령 후 초임계 이산화탄소 조건에서 탄산화 반응시킨 시험체의 TG/DTA 측정 결과이다. Fig. 4의 결과를 확인해보면 각 그래프마다 $\mathrm{CO}_{2}$ 의 가스화 구간인 약 $800^{\circ} \mathrm{C}$ 부근에서 흡열반응 피크가 발생하여 무게감소가 있는 것으로 보아 모든 시험체가 탄산화가 이루어 진 것으로 판단된다. 또 한 모든 그래프에서 $100^{\circ} \mathrm{C}$ 이하의 부근에서 흡열 반응 으로 인한 무게감소가 발생하였고 비산회 치환율이 증가 할수록 감소량이 증가하는 것을 볼 수 있는데 이것은 시 멘트의 함량이 적어질수록 포졸란 반응에 사용되지 못한 $\mathrm{H}_{2} \mathrm{O}$ 가 증가하여 측정 시 $100^{\circ} \mathrm{C}$ 이하구간에서 증발하는 수분량이 많아진 것으로 사료된다. Fig. 4에서 보듯이 $800^{\circ} \mathrm{C}$ 부근의 무게감소를 비교해보면 FA10, FA20, FA30, $\mathrm{FA} 40$ 의 시편은 각각 $8.03 \%, 8.81 \%, 8.91 \%, 9.21 \%$ 의 무게감소가 발생하였으며 이는 비산회의 치환율이 증가 할수록 무게감소가 증가하는 경향을 나타내고 있다. 이

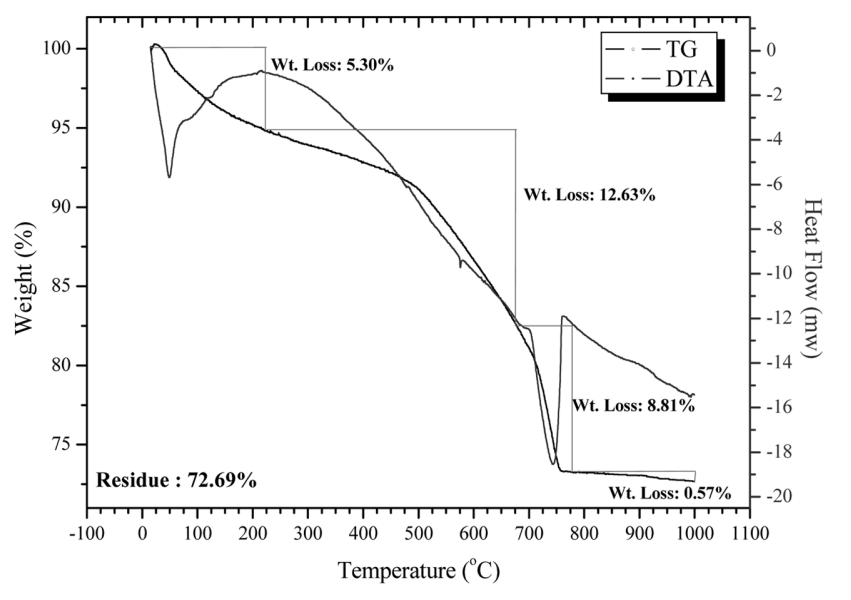

(b)

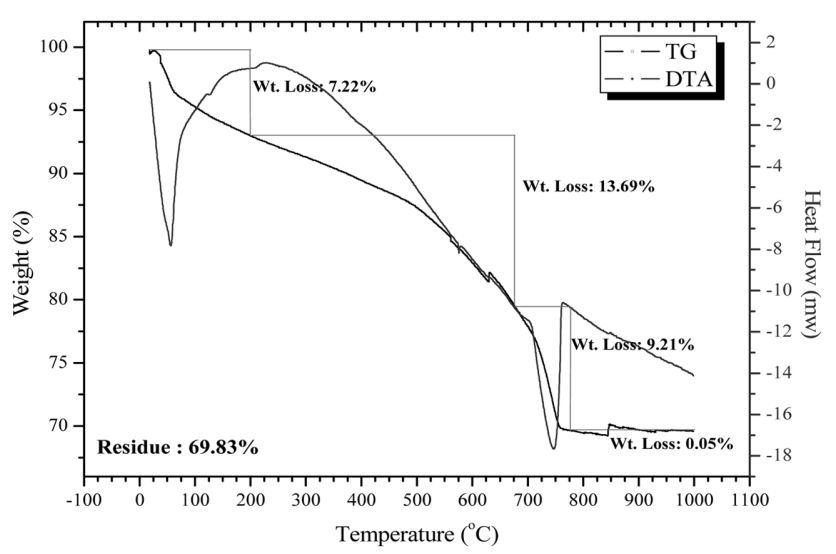

(d)

Fig. 4. TG/DTA analysis of fly ash substituted mortars after the carbonation for 28 days. (a) FA 10, (b) FA 20, (c) FA 30 and (d) FA 40. 


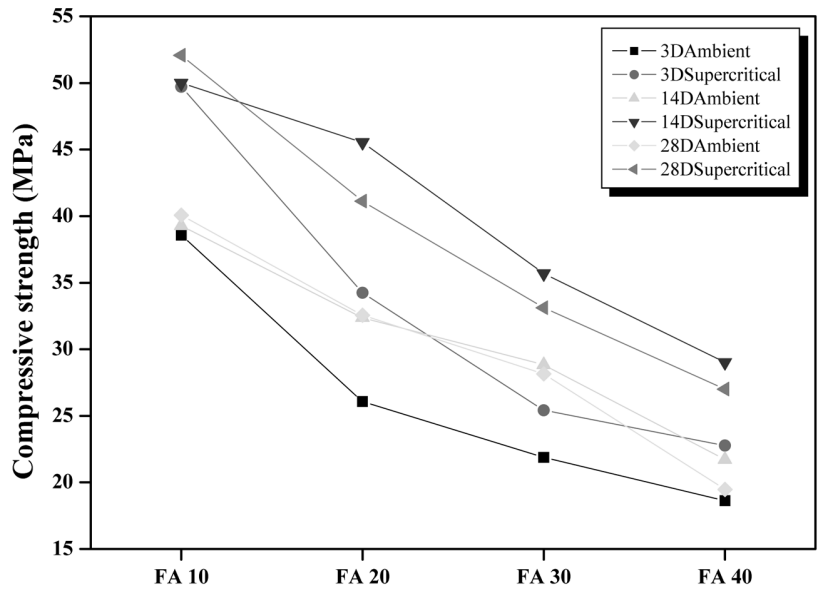

Fig. 5. Compressive strength of fly ash substituted mortars before and after the carbonation and after the carbonation. Where, 3DAmbient in the inlet means 3 days curing under the ambient condition and 3DSupercritical, 3 days curing under the ambient condition and then carbonated under the supercritical condition $\left(80 \mathrm{kgf} / \mathrm{cm}^{2}\right.$ and $\left.40^{\circ} \mathrm{C}-60 \mathrm{~min}\right)$. The remaining notations can be identified as same way as above.

것은 무게변화율과 $1 \%$ 페놀프탈레인 용액 분무 시 나 타난 결과와 일치하는 결과로 비산회 치환량이 증가할수 록 비산회의 free-CaO 함량이 많아져 상대적으로 높은 탄산화 반응이 초임계 상태에서 진행된 것으로 판단되며 결정수 증발 구간인 약 $500 ~ 600^{\circ} \mathrm{C}$ 부근에서 미미한 흡 열 피크 구간이 확인되므로 시험체들이 완벽히 탄산화 되지는 못한 것으로 사료된다.

탄산화에 의한 기계적 물성향상을 확인하기 위해 압축 강도를 측정하여 Fig. 5에 나타내었다. 일반적으로 ASTM C Type 비산재를 시멘트 대체로 치환할 경우 압축강도 는 저하되는 것으로 알려져 있는데[1] 본 연구의 결과에 서도 상온, 상압하에서 양생한 후 시편들은 참고문헌의 결과와 동일하게 비산재 치환량이 증가할수록 압축강도 는 저하되는 것으로 나타났다. 또한 비산재의 치환량이 많아질수록 장기재령 시 재령 14 일차보다 28 일차의 압 축강도가 저하되는 것으로 나타내어지는데 이는 비산재 의 free- $\mathrm{CaO}$ 팽창에 의한 미세 균열이 발생하여 압축강 도 저하가 나타난 것으로 사료된다. 그러나 초임계 이산 화탄소 조건에서 탄산화 반응시킨 시험체의 경우 탄산화 반응 전 시험체보다 상당한 수치의 압축강도 향상을 확 인 할 수 있었다. FA10 시험체의 경우 재령 28 일차 초 임계 탄산화 후 압축강도가 초임계 반응 전 시편과 비교 하여 약 $30 \%$ 정도 증가되었으며 FA20 시험체의 재령 14 일차 초임계 탄산화 후 압축강도는 약 $40 \%$ 이상 증 가한 $45.54 \mathrm{MPa}$ 로 $\mathrm{FA} 10$ 의 28일차 압축강도인 40.07 $\mathrm{MPa}$ 보다 더 높은 압축강도 값을 나타내고 있고 재령 28 일차 탄산화 후 압축강도 또한 FA10의 28 일차 압축 강도보다 높은 값을 나타내고 있다. 다른 시험체도 동일 하게 초임계 이산화탄소 조건에서 탄산화 반응시킨 후의

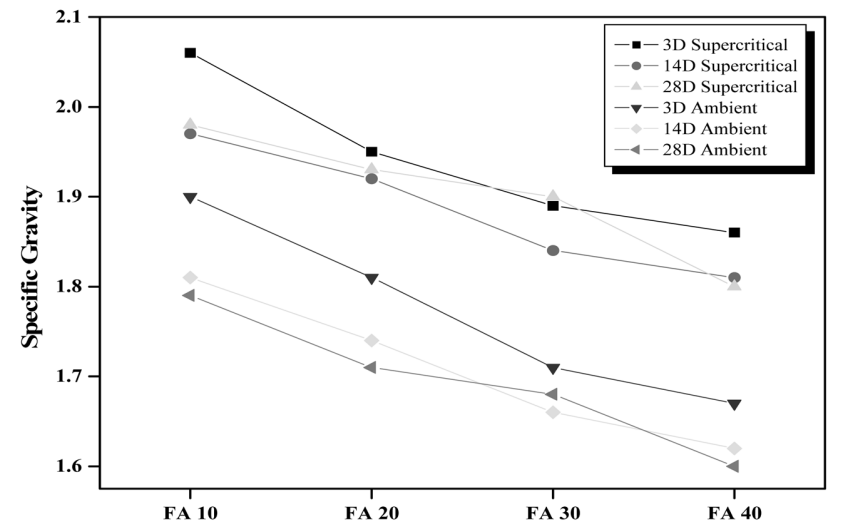

Fig. 6. The specific gravity of fly ash substituted mortars before and after the carbonation under the supercritical condition. Where, 3D Supercritical means 3 days curing under the ambient condition and then carbonated under the supercritical condition $\left(80 \mathrm{kgf} / \mathrm{cm}^{2}\right.$ and $\left.40^{\circ} \mathrm{C}-60 \mathrm{~min}\right) .3 \mathrm{D}$ Ambient, 3 days curing under the ambient condition. The remaining notations can be identified as same way as above.

압축강도는 탄산화 전의 압축강도보다 상당히 증가되어 진 것으로 보여진다. 이는 $\mathrm{Ca}(\mathrm{OH})_{2}$ 의 상이 $\mathrm{CaCO}_{3}$ 상으 로의 전환으로 인해 반응생성물이 시험체 내부의 미세한 기공을 메우는 효과를 얻음으로써 경화체 자체의 압축강 도가 증가된 것으로 탄산화 반응 시 최소 $15 \%$ 이상의 압축강도 향상이 가능할 것으로 사료된다.

제작된 시험체의 파쇄형 인공경량골재의 조건을 충족 하는지 확인하기 위하여 절건비중을 측정하여 그 결과값 을 Fig. 6에 나타내었다. 시험체의 비중은 FA10의 재령 3 일차 초임계 이산화탄소 조건에서 탄산화 반응시킨 시 험체를 제외한 모든 시험체들이 인공경량골재 조건인 비 중 2.0 이하의 조건을 만족하였으며 FA40의 재령 28 일 차 탄산화 시험체는 비중 1.8 로 탄산화 반응시킨 시험체 중 가장 낮은 비중값을 나타냈다. 대체적으로 초임계 이 산화탄소 조건에서 탄산화 반응시킨 시험체들은 탄산화 하지 않은 시험체들보다 높은 비중값을 나타내는데 이는 탄산화 반응 시 $\mathrm{Ca}(\mathrm{OH})_{2}$ 상에서 $\mathrm{CaCO}_{3}$ 상으로 전환될 때 질량증가 및 부피팽창으로 인해 기공이 메워지면서 비중값이 증가한 것으로 사료된다.

분석된 데이터를 토대로 비산재를 시멘트 대비 일정량 치환시키면 시멘트 경화체 및 파쇄형 인공경량골재 제조 시 초임계 이산화탄소 조건에서 탄산화 반응을 유도하여 압축강도를 15 40\% 범위에서 향상 시킬 수 있으며, 2.0 이하의 인공경량골재를 제조할 수 있을 것으로 판단된다.

\section{4. 결 론}

비산재를 시멘트 대비 일정량을 치환하여 각 재령일마 다 초임계 이산화탄소 조건에서 탄산화 반응을 유도시킨 
후 무게변화율, 탄산화깊이, TG/DTA 분석 및 압축강도 와 비중을 측정하여 상온, 상압 조건에서 양생시킨 경화 체와 초임계 상태에서 탄산화 시킨 경화체의 물성을 비 교한 결과 다음과 같은 결론을 얻었다.

1) 시멘트 대비 비산재의 치환율이 증가할수록 비산재 내부의 free- $\mathrm{CaO}$ 에 의해 초임계 이산화탄소 조건에서 탄산화 반응 시 비산재 치환율 $40 \%$ 의 경우, 재령 28 일차에서 $13 \%$ 의 높은 무게변화율과 TG/DTA 상에서 $9.209 \%$ 의 높은 이산화탄소 탄산화 효율을 나타내었다. $1 \%$ 페놀프탈레인을 분무하여 탄산화 깊이를 측정 시 비산재의 치환량이 증가할수록 탄산화 반응 정도가 눈에 띄게 증가하는 것을 확인할 수 있었으며 또한 재령일수 가 증가할수록 탄산화 인자인 $\mathrm{Ca}(\mathrm{OH})_{2}$ 의 생성이 증가하 여 탄산화에 유리한 조건을 충족시킬 수 있었다.

2) 비산재의 치환율이 증가할수록 시험체의 압축강도 가 저하되지만 초임계 이산화탄소 조건에서 탄산화 반응 을 유도하면 비산재를 시멘트 대비 $20 \%$ 를 치환시 재령 14 일차에서 최대 $40 \%$ 정도의 압축강도 향상을 나타내 었으며, 다른 시험체의 경우에도 최소 $15 \%$ 이상의 압 축강도 향상을 얻을 수 있다.

3) 초임계 이산화탄소 조건에서 탄산화 반응시킨 시험 체 경우 탄산화 전 시험체보다 높은 비중값을 나타내지 만 비산재 치환량이 증가할수록 비중값은 낮아지며 28 일 재령시 모든 시험체가 인공경량골재 조건인 2.0 이하 의 비중을 만족하는 것으로 확인되었다.

\section{감사의 글}

이 논문은 경기대학교 산학협력단에서 지원하는 2010 년도 $21 \mathrm{C}$ 프론티어사업 연구재투자 학술연구비 지원 관 리번호 2010-0480에 의하여 수행되었습니다.

\section{참 고 문 헌}

[1] K.G. Lee, "Bloating mechabism of artificial lightweight aggregate with reject ash", J. Kor. Crystal Growth 22[3] (2012) 158.

[2] H.J. Kim, Y.T. Kim and C.S. Jang, "Characteristics of geopolymer based on recycling resources", J. Kor. Crystal Growth 22[3] (2012) 152.

[ 3 ] Y.J. Choi and Y.T. Kim, "Effect of EAF dust on the formation of ultra lightweight aggreates by using bottom ash and dredged soil from coal power plant”, J. Kor. Crystal Growth 21[3] (2011) 129.

[4] N.S. Ahn, J.H. Lee and Y.H. Lee, "Sulfate attack according to the quantity of composition of cement and mineral admixtures", J. Kor. Building Construction Ins. 11[6] (2011) 547.

[ 5 ] J.Y. Park, Y.T. Kim and H.J. Kim, "Carbonation of coal fly ash for construction materials", J. Kor. Crystal Growth 22[3] (2012) 147.

[6] S.H. Hong, B.D. Lee and S.H. Han, "Application of fly ash concrete in the pavement", J. Kor. Concrete Ins. 20[1] (2008) 701.

[7] J.S. Sim, K.G. Lee, Y.T. Kim and S.K. Kang, "Hydration characteristics of coal-fly ash containing high $\mathrm{CaO}$ compound", J. Kor. Ceramic Soc. 49[2] (2012) 185.

[8] W.S. Kim, T.K. Kang, M.S. Paik, S.S. Kim and S.J. Jung, "The experimental study on carbonation properties of high volume fly-ash concrete", J. Kor. Architectural Ins. 23[1] (2003) 207.

[9] H.S. Ahn, J.S. Kim and H.S. Lee, "A study on fixed amount of $\mathrm{CO}_{2}$ and the estimation of production of $\mathrm{CaCO}_{3}$ on waste concrete powder by wet carbonation", J. Kor. Architectural Ins. 27[7] (2011) 133.

[10] I.T. Kim, H.Y. Kim, G.I. Park, J.H. Yoo and J.H. Kim, "Effect of carbonation reaction of portlandite with supercritical carbon dioxide on the characteristics of cement matrix", Applied Chemistry 5[1] (2001) 60. 